\title{
Justice and Righteousness in Post-Communist Societies - The Case of Croatia
}

\author{
Karmen Skube \\ Public Administration and Independent Researcher, Karlovac, Croatia
}

Email address:

karmen.skube@gmail.com, karmen.skube@public.carnet.hr

\section{To cite this article:}

Karmen Skube. Justice and Righteousness in Post-Communist Societies - The Case of Croatia. Journal of Political Science and International Relations. Special Issue: Corruption as a Systematic Issue in the Developing Countries. Vol. 3, No. 1, 2020, pp. 16-25.

doi: $10.11648 /$ j.jpsir.20200301.13

Received: March 11, 2020; Accepted: March 24, 2020; Published: April 14, 2020

\begin{abstract}
Can Croatia, as a transition country, be put in the category of democratic states? Yes, if by democracy we consider only implemented mechanisms, which provide a formal democratic procedure for the election of power holders, and guarantee certain political rights and freedoms, such as freedom of speech, opinion, assembly or association. However, if we describe the concept of democracy as a political system that serves the people through a democratically elected government, guaranteeing every citizen the right to work, prosperity, equality before the law, justice, righteousness, equal opportunity for every member of society, but at the same time if we take into account that it has no control over it, Croatia is still at the beginning of its democratic development. There are numerous obstacles along the way. The aftermath of the war, and the poorly implemented transformation of the inherited socialist political order and economy based on self-management of social property, opened the way for the development of corruption into a disease of the system, as well as political clientelism and conflict of interest as a way of functioning of political elites. The consequence is the stratification of the Croatian society in material terms, and the division in ideological and world-view issues. Structural reforms in all areas of society, starting from the political system, the public administration system, the health, education and justice systems are a precondition for Croatia's development towards true democracy, in which every individual will be provided with the so-called the rights of the first, second and third generation. In order to carry out the reforms, the political will of the authorities is crucial, the imposed system of value, partly inherited from the period of socialism and partly formed in the beginnings of the functioning of a newly founded state, must be changed through reforms.
\end{abstract}

Keywords: New Justice, Post-conflict Transition States, Duopolism of the Political System

\section{Introduction}

The campaign for re-election of the President of the Republic of Croatia, Dr. Ivo Josipović, was based on a program that emphasized the need for further development of the Croatian society, based on the principles of justice and righteousness [1].

Dr. Josipovic failed to win the new term, and the program which was called New Justice remained only a dead letter on paper.

The author of the article will identify the main problems and causes that are slowing down Croatia's development into a modern, European, economically prosperous state based on the principles of justice and righteousness.

In the analysis it is necessary to start from certain specifics, which had a decisive influence on the beginning of functioning of the newly founded state. These specifics relate to the transition process of an inherited socialist political and economic system implemented in the context of leading a defensive war.

According to Horowitz, the negative effects of war on the democratization of society and the implementation of market reform through the transition process are visible in the form of accumulation of political power, lack of tolerance towards political opposition, the media, restriction of human and political freedoms, strengthening of political repression, and economic favoring of individuals or groups, while resisting the implementation of structural reforms [2].

Also, in accordance with the aforementioned conditions in the transition, processes were conducted, international 
institutions rank Croatia in the group of transitional postconflict countries [3]. This grouping of countries is made up of states that emerged after the breakup of the former federations, which had to defend their newly-acquired independence and state borders with weapons, and therefore their transition process simultaneously involved building the state and nation, market economy and democracy [4].

Consequently, in the case of Croatia, together with other countries of the former Yugoslavia and some former Soviet republics, we can speak of the so-called. "quadruple transition" $[2,5]$.

Namely, a conditional division into a "double", "triple" and "quadruple" transition has emerged in science. Thus, the "double" transition covers the process of economic and political transformation (Poland, Hungary, Czech Republic), the "triple" transition covers democratization / marketisation / state building (other countries of Central-Eastern Europe), while the "quadruple" transition includes democratization / marketisation / state / national-building, as was the case with the countries of the former Yugoslavia, USSR, Slovakia [6, 7].

Therefore, it is necessary to explain the internal sociopolitical circumstances in which this "quadruple" transition took place, because they have decisively influenced the further direction of Croatia's development. These circumstances address the issue of the existence of weak political institutions, which were just in the initial stages of construction, with no experience and tradition of functioning on the principles of "good government"; then, the structure and composition of members of the political elite of the time as the bearers of the transition process; the lack of awareness of the public and political elites about the necessity of changing the way of thinking and acting in the past, typical for the inherited socialist political and economic systems, and the problem of implementing a policy of economic transition based solely on the category of property. By analyzing the above mentioned circumstances, the author of the article will try to explain the causes of today's weaknesses in the Croatian society. Political clientelism, conflicts of interest of holders of political and economic power, systemic corruption, the absence of a value system based on democratic principles are the main obstacles to Croatia's development today.

The World Bank has warned about the emergence of certain forms of corruption during the process of transforming the political and economic system. The very fact that the said process took place under the conditions of the newly established legislative and institutional framework, enabled an uncontrolled concentration of economic power in the hands of particular interest groups, closely related to political centers of power [3].

\section{Transition Processes}

At the beginning of the last century, Croatia, as well as other countries of the former socialist socio-political system, was confronted with the need to carry out transition processes, through which it had to simultaneously ensure the transformation of society in two directions: from the political and economic order - the so-called self-governing socialism, with social ownership as a prominent value, into a model of society based on democratic mechanisms and market conditions of business. Here, the notion of self-governing socialism should be distinguished from the notion of socalled real socialism, typical for other post-communist countries. "Real socialism was created on the basis of negation and the market and democracy", while "selfgoverning socialism developed on the foundations of the market, labor democracy, social ownership and selfgovernment" [8].

Welsh explains the term transiton period as "the interval between an authoritarian political regime and a democratic one" [9]. Transition is a long-term process, consisting of changing the political and economic system. This change in the case of post-communist countries had to take place simultaneously to democratize society and introduce market rules in the economic sector. Changes in the economic system are conditioned by changes in the political sphere. According to Horrowitz "In the post-communist world, democratization was typically a prerequisite for dismantling planned or socialized economies and instituting market-based ownership" [2]. Croatia is an example of a transition country which has been in an economic recession for many years precisely because of the lack of key reforms political system.

\section{Transformation of the Political System}

In the process of transformation of the inherited socialist socio-political system, a framework had to be set for the implementation of all those democratic mechanisms typical for societies with a long democratic tradition, such as pluralism of opinion, political activity, freedom of assembly, speech, writing, voting. This was supposed to be the foundation upon which the democratic process of electing government at local, parliamentary and presidential levels would rest.

However, true democracy is not only represented by these characteristics. The fundamental meaning of democracy is that democratically elected officials serve for the benefit of all citizens, promoting the public interest as a whole. Otherwise, these democratic mechanisms may serve political elites to gain power in order to protect exclusively the particular interests of individuals and groups. This opens the door to an undemocratic way of governing and a turn towards qualification, the notion of "bad government or simply government by the most unscrupulous or unsuitable people" [10].

Consequently, when talking about democracy, one should distinguish between the fact that a democratic state implies the existence of a democratic government, but also that a democratically elected government does not need to guarantee the existence of a democratic state.

Distinguishing the understanding of democracy as a political system and democracy as a form of government is 
the factor that distinguishes countries with a long tradition of democracy from other states, which yet have to develop the said political system of government.

In a democratic political system, the responsible government acts in the interest of all citizens, enabling the application of democratic mechanisms to formulate their interests, by ensuring "alternatives to expression, right to vote, right to political leaders to compete for support, alternative sources of information, free and fair elections, right of political leaders to contest for votes, institutions for making government policies depend on votes and other expressions of preference " [11].

If we compare the above mentioned with the process of transition of the political system in Croatia, we can see a gap between the implemented mechanisms, through which the citizens could democratically elect the holders of power and ruling of political elites. The actions of political elites are not always in line with all democratic principles of good governance. The notion of good governance not only defines the way government works, but also applies to all other actors in society; political parties, parliament, the judiciary, the media, civil society, and their interactions with each other, all with the aim of improving citizens' standards. The tripartite formula for good governance encompasses the elements of

"State capability - the extent to which leaders and government are able to get things done.

Responsiveness - whether public policies and institutions respond to the needs of citizens and uphold their rights; Accountability - the ability of citizens, civil society and the private sector to scrutinize public institutions and governments and hold them to account" [12].

The type of party system, the type of political parties and the way they function are key to the functioning of the overall political system. If they operate in the conditions of unsettled legislative and institutional frameworks of society, they become the main source of corruption and political clientelism. According to Bandelj \& Radu "political transformations in postcommunist Europe need to take into account the specific historical and socio-economic context of large-scale post-socialist transformations in this region " [7].

As in the case of other countries of Eastern and Southeastern Europe, the Croatian political scene was marked in 1989 and 1990 by the beginnings of a change in the political system from a one-party system, dominated by the Communist Party for decades, to a multi-party system [7].

The peculiarity of the first democratic elections, held in May 1990, is that they were held at a time when Croatia had not yet gained its independence, because it was part of the former Yugoslavia, and the elections themselves were held in the atmosphere of war threats in the territory of the former Yugoslavia. Ekiert at al. emphasize that the bloody civil war in the former Yugoslavia and its legacies are a stark reminder of the potential difficulties faced by divided societies in their quest to build democracy" [13].

However, in the long run their results will influence the creation of the Croatian political space. Its basic feature is the existence of bipolar multipartism, in which two political parties of the left and right center have been alternating power for the past 25 years. As a rule, only two parties won the biggest number of votes in the parliamentary elections: HDZ and SDP, which formed governments with their coalition partners: from 1990 to 2000 - HDZ; from 2000 to 2003 - SDP; from 2003 to 2011 - HDZ; from 2011 to 2016 SDP, and from 2016 to present - HDZ.

Also, by analyzing the results of the first multi-party elections for members of the Croatian Parliament, certain comparisons can be made with other countries of the former socialist political system, which indicate that the first free elections in those countries turned into certain "essentially plebiscites against Communist Party and protest against the existing political system: the elections were mainly protest votes against the former regimes " [14]. On the Croatian political scene, between the 33 political parties and 16 different associations registered for the elections, two main parties or two poles stood out, which exist to this day [15]. The largest number of seats in the first multi-party elections was won by the Croatian Democratic Union - HDZ (205 or 58\%), and the Reformed Communists Party - the League of Communists of Croatia - Party for Democratic Change - SKH-SDP (107 seats or $30 \%$ ). Compared to ideologically "sister" parties in Czechoslovakia (Communist Party won 14\% of votes), Hungary (Socialist Party won 11\%) in East Germany (Party of Democratic Socialism won $16.4 \%$ ), only reformed communists in Croatia, and in Bulgaria (Socialist Party won 44\%), they achieved good results [14].

The Croatian Democratic Union (HDZ), as the strongest political party, emerged from the national independence movement, taking on the character of a mass party led by a charismatic leader.

Reformed Communist Party of Croatia - Social Democratic Party of Croatia (SDP) has profiled itself as the largest opposition political party since the early $2000 \mathrm{~s}$.

Through the activities of these two main political parties, one can see the overall process of democratization of the Croatian political system. This process can be provisionally divided into two time periods - from 1990 to 2000, and from 2000 to the present.

To draw parallels between the presentation of the transformation of the political system over the specified time period, it is necessary to analyze the structure of the members and the leadership of the newly formed political parties.

From the aspect of influencing the creation of party and national politics, there are two basic categories of members of political parties: former members of the Union of Communists of Yugoslavia, and members of the Croatian diaspora.

By joining the newly formed political parties, former members of the League of Communists of Yugoslavia took prominent positions in the new pluralist party system [16]. After the breakup of the former Yugoslavia and the establishment of new states within the territorial borders of the former republics in Croatia, the League of Communists of 
Croatia changes its name to the Party of Democratic Change (SKH-SDP), and then to the Social Democratic Party (SDP).

Simultaneously with the process of transformation of the SDP, as the sole successor to the former Communist Party, a large number of political parties was formed, with a large number of former Communists joining, for example, the Croatian Democratic Union (HDZ); The Croatian People's Party - HNS, and the Serb ethnic minority party - the Serb Democratic Party (SDS), which ceased to exist after the end of the Homeland War. Some of its members are now politically active in the Inedependent Democratic Serbian Party (SDSS).

So, regardless of the political program of the new political parties, they had one thing in common - the former communists became members of the mentioned parties, and their influence, after the first multi-party elections, was not weakened. The described pattern of rapid transformation of politicians with many years of experience in the one-party system is found in other post-communist transitions. According to Stoica " Romania is a country marred by former communist politicians' survival", in which the positioning of former communist elites in the new authorities has led to the establishment of the so-called "mock democracy," controlled by an incompetent, highly politicized, and excessive bureaucracy, as well as an "economic system that rewards politically-connected individuals or firms and punishes honest, hard-working entrepreneurs" [17].

The second category of party members was represented by members of the Croatian diaspora, especially part of the political emigration, who returned to Croatia in the early 1990s.

The very term "diaspora" does not refer exclusively to "the objective group of people but always the result of social or political mobilization, with foundation myths, rituals and representative organizations" [18].

In order to understand their role in the construction of the new political and economic system of Croatia, it is necessary to explain the genesis of their emergence.

During the 20th century, the Croatian diaspora, as part of the total Yugoslav emigration, had three major emigrant waves, whose actors can be divided into three categories "old emigrants", "political emigrants" and "quest workers" $[18,19]$.

The "Old Emigrants" were emigrants, mostly members of the peasantry and the working class, who left the AustroHungarian Monarchy from 1880 to 1914 , which at that time comprised areas of present-day Croatia.

The next group (with two groups provisionally speaking) was represented by "political emigrants" - Croatian emigrants who left Yugoslavia after 1945 and the collapse of the Quisling state formation of the Independent State of Croatia. The aforementioned group of emigrants was marked by the Calvary of the "Cross Road" and the mass liquidations at Bleiburg [20]. This group was represented by members of the middle and upper classes, who were treated by enemy emigration by the Yugoslav Communist leadership.

Another subset of political emigrants emerged after the collapse of the so-called MASPOK (mass national movement) in Croatia, that is, the "Croatian Spring" in late 1971 and during 1972 [21]. This movement was led by Communist leaders of the younger generation and liberal orientation, who "made genuine efforts to broaden the regime's social base to increase Croatia's autonomy within the Yugoslav Federation" [16]. The consequences of its collapse were reflected in the entire Croatian society in terms of the imposition of the "ideological dictatorship" by the League of Communists of Yugoslavia in all areas of social life, from social, cultural, to educational [16]. This was followed by persecution, intimidation, imprisonment for prominent members of the movement, and the elimination from political life of its major leaders, from Dr. Savka Dabcevic-Kuchar, Mike Tripal to Dr. Franjo Tudjman and other high-ranking members of the communist elite.

The third group of emigrants consisted of "guest workers" or temporary workers abroad. They were one of the "consequences" of the Communist leadership's attempt to carry out economic reforms during the 60 years of the last century, by introducing certain elements of a market economy. The reform failed because the Yugoslav economy, with the exception of the Croatian and Slovenian economies, was not ready to function on a market basis. The result of this experiment was a large increase in unemployment, which the Communist leadership "regulated" in such a way that it liberalized going abroad and thus solved two problems: it reduced unemployment and the number of political opponents of the regime, allowing them to go temporarily abroad.

After winning the first elections in 1990, the HDZ held power until 2000, winning two consecutive election cycles for the Croatian Parliament. The aforementioned decade of HDZ rule was marked by the Homeland War (1991-1995) and the transition process, during which the rule of the leading political party was based solely on the issue of national identity, as a mobilizing factor, instead of the priority task of implementing structural political and economic reforms. According to Bandelj and Radu "Democratic consolidation will be faster when the elites in power have a pro-democratic reform orientation, defined quite minimally as a government, where the ruling party is not a nationalist nor communist in orientation" [7]. The tenyear rule of HDZ has adversely affected the transition process of the Croatian society, and opened up the space "toward greater authoritarianism and greater corrpution" [13]. It was the absence of political will for consistent and thorough transformation processes during the 1990s that favored the spread of corruption and clientelism, and, in that period, classified Croatia as a group of countries with "illiberal democracies", together with Slovakia, Bulgaria and Romania [22].

During this period, the main opposition party, SKH-SDP, as a successor to the former Communist Party, reformed into a center-left Democratic Party, renamed as Social Democratic Party (SDP). In the next parliamentary elections in 2000, SDP won power with the center-left coalition of six political 
parties, which ushered in a new era of intense democratization, a result that put Croatia in the group of post-communist countries with consolidated democracy over the past decade.

With the onset of democratization, the process of accession negotiations for Croatia's full EU membership opened.

These processes influenced the main opposition political party - HDZ, to begin its internal reform from a political party based on national ideology to a modern European Christian Democratic Party, a member of the European People's Party, which won the next parliamentary elections in 2003 and 2007.

After the opening of accession negotiations with the EU, the democratic processes of Croatian society intensified, in accordance with the dynamics of opening negotiation chapters with well-defined conditions set by the EU. A particularly significant shift has been noted in the implementation of the anti-corruption strategy.

However, after gaining EU membership (in July 2013), Croatia stalled in implementing the key reforms necessary to further democratize society, primarily because of the lack of political will to carry out structural reforms systematically and thoroughly.

This is due to the crisis of the party system. As well as in developed European countries, the transformation of a massive political party into a type of professional electorate is at work in Croatia. The characteristic of mass parties is the mobilization of a particular stratum of citizens on the question of ideology or nationality, thereby creating "a large base of dues-paying members, hierarchically structured party organizations linking the national and local levels" [23]. Today, the tendency in the Croatian political space is to separate political parties from society and to firmly attach them to the state (or rather to the state budget, from which they are largely financed). Contact with their own electoral base is lost, elements of democracy disappear, as party leaderships represent narrow elitist groups of people, led by an undisputed leader, of an authoritarian way of governing. The decision-making process is in the hands of several people - the president of the party and his closest associates, while "ordinary members" are used as "voting machinery", which is initiated and motivated exclusively on the eve of each election cycle. It is precisely the exclusive right of a few party people to create party politics that directly affects the party's undemocracy, since the electoral base deprives the possibility of any control over the actions of the party leadership, which opens the space for the arbitrariness of party leaders and their associates. Thus, a common feature of all political parties in Croatia is the persevering cultivation of a kind of dirigiste democracy which is used to control their activities in the national political space by the party's leader and his closest associates [24]. Furthermore, the closest associates, as a rule, are recruited from like-minded circles, who base their political existence on the unconditional obedience and loyalty of the party leader. The consequences of this are visible in the crisis of identity of political parties, because, according to Walter Lippman, "where all think alike, no one thinks very much" [25]. Also, in order to make the political parties more efficient on the aforementioned grounds, they have built strong and expensive professional apparatus. Such functioning of party management, by the method of "domino effect", also affects the behavior of other party members. Namely, when they join a political party, they see an opportunity to realize certain personal gains, materially or career-motivated (securing employment / leadership in public administration, or in public companies for themselves and family members, membership in the supervisory and management boards of state-owned companies, and other forms of bargaining). As a result, noncore party members become mere followers and obedients of their party leaders with the ultimate goal of securing their own gains. Consequently, a layer of people with average / below average abilities and knowledge, above average ambitions, and a very important characteristic of "political" obedience, is recruited into various institutions within the public administration system (state administration, public services, local and regional self-government units).

Looking back at the current stages of the development of the political system in Croatia, one can see a certain pattern of functioning of the same, in the sense that the step in the democratization of the Croatian political system, as a rule, depends on the degree of democracy within the leading political parties.

According to the above mentioned conditions in which political parties function in Croatia, it is exactly their undemocratic organization that generates political clientelism, conflicts of interest at all levels of society, and institutional or systemic corruption that has become a generally accepted way of life. This is also evident through the perception of corruption in post-communist societies see. Sajó who explains the increased perception of corruption in post-communist countries from several points of view: moral, cultural, historical, institutional and political and states that it is not the result of the absence or termination of citizens' trust in public servants, but is the result of "the needs of the political structures" [26].

Writing about political corruption, Issacharoff states that "the existence of public power is an opportunity for motivated special interests to seek to capture the power of government, not to create public goods, but to realize private gains through subversion. of state authority " [27].

On the other hand, the term of political clientelism could be explained as a patron-client relationship in which a political exchange between the politician ("patron") and the client is realized in the sense of giving patronage for the vote or any other kind of support of a client [28].

Conflict of interest "exists when a public employee's public responsibilities clash, or appear to clash, with his or her private economic affair" [29]. The same can be said to overlap with corruption in the sense that corruption cannot exist without a conflict of interest, because each and every corrupt act is driven by an underlying conflict [30].

It can be concluded that the absence of a tradition of Western-style political pluralism is a common "childhood 
illness" of all post-communist countries, but also developed countries are not immune to these "democracy faults" [9, 31].

\section{Transformation of the Economic System}

In the process of transforming the inherited socialist economic system into a market economy, there was a certain difference between Croatia and other Central and Eastern European countries. Namely, the transition of the economic system in Croatia took place in two phases: through the transformation of socially-owned enterprises (with the aim of transforming social ownership into state ownership) and privatization (with the aim of transforming state-owned into private ownership). The aforementioned difference stems from the fact that Croatia, together with other republics of the former Yugoslavia, has based its economy on the already mentioned model of the so-called of self-governing socialism.

The main emphasis in the conversion and privatization processes was on the key issues of ownership of SOEs, major discrepancies between their real market value and their selling price, and consequently the issue of selling them to "buyers who have no money" [32].

It should be emphasized that the transformation of the economic system was carried out partially, based solely on the change of ownership of enterprises. Meanwhile, reforms in other areas closely related to the economy have been left out. Under the overall transitional processes of the economic system, Welsh implies the implementation of a group of reforms: "macroeconomic stabilization (e.g. reform of monetary and fiscal policies), price reform (e.g. price liberalization, currency convertibility), structural reform (e.g. privatization, trade liberalization), institutional reform (e.g. reform of legal and banking systems) and educational reform (e.g. management training)" [9].

In addition, Croatian transition has been characterized by several other problems common to post-communist countries: delays in the implementation of market economy mechanisms, failure to respect the principles of justice, equity, social insensitivity to the problems and needs of vulnerable groups in society [13].

According to Ekiert at al. transition processes had to be carried out in such a way that the political elites had to take into account the transparency and legality of the procedures, clear and realistically set ultimate goals of the transition, and with a built legal and institutional framework, which should ensure the rule of law [13].

By analyzing the transition models through which postcommunist countries have more or less successfully implemented market economy mechanisms, Izymov \& Claxon identify three basic models: democratic capitalism (Baltic countries, Hungary, Poland, The Czech Republic, The Slovak Republic, Slovenija); autocratic capitalism (Central Azian countries) and clan capitalism (Albania, Bulgaria, Romania, Armenia, Moldava, Russia, Georga, countries of the former Yugoslavia) [33]. As the basic difference between democratic capitalism and the other two models, Izuymov \& Claxon point out the "the strong role of the civil society and effective separation of economy and polity found in democratic capitalism" and conclude that the above mentioned circumstances allow interest groups in countries where the last two autocratic and clan capitalism models are applied to completely or almost completely control the economy, pursuing their own interests [33].

Kosals gives an explanation of the term "clan capitalism" as an example of transition processes in Russia [34]. Kosals describes the term as "social entity united by the common interest of survival in the hostile social Soviet environment and bound by shadow relations regulated by hidden norms", emphasizing that "clans formed a system of 'clan capitalism ' as a result of daily interactions with each other and the government promoting policy of market transformation" [34]. As a rule, these clans are a union of business people, politicians, members of the intelligence system, and members of the criminal milieu, who are not fully subject to the control of institutional authorities. It should be emphasized that one part of business people belonged to the so-called economic elite of the socialist era (former directors of socially owned companies), some of the politicians and intelligence officials, as already mentioned in the previous chapter, were members of the former socialist political and intelligence nomenclature. According to Kosals, their power was based on the control of economic, administrative or political, as well as judicial resources, enabling the above-mentioned clan structure to control all spheres of society, in order to prevent the implementation of market economy mechanisms [34]. The consequence of the imposed structure of relations in political-entrepreneurial-criminal groups is the creation of a model of "crony" capitalism, which is a common characteristic of a part of countries in transition. In the case of Bulgaria, this model is described as a "nonplanned and nonmarket system", functioning under conditions of underdeveloped institutions of government, lack of market mechanisms, post-socialist lobbying culture (rent-seeking), and the emergence of quasi entrepreneurs and owners [35].

\subsection{Transition}

The process of economic transition in Croatia involves about 4,000 socially-owned enterprises, with a total value of $\$ 20$ billion, which were subject to conversion as part of the process of overall reform of the Croatian economic system [36]. The law established the following four conversion models: the sale of all or a part of the enterprise to a natural or legal domestic or foreign person; by investing in the company (through the issue or payment of shares); converting earlier investments in the enterprise and receivables of the enterprise into a stake; transferring all shares / units into government funds free of charge.

For the most part, the conversion was carried out according to the first model in such a way that the majority of stocks / shares of socially-owned enterprises were sold under favorable conditions to managers, employees and former 
employees within these enterprises, which made these categories of persons privileged in relation to other citizens. This model introduced the so-called system of "small shareholders", while the other dominant form of conversion was the sale of shares / stocks to outside investors, so it can be concluded that the prevailing conversion model was a combination of the so-called internal and external privatization.

The aim of the conversion, which had to be completed by the statutory deadline (until 30 June 1992), was to make all socially-owned enterprises (except the grouping of those of strategic national importance) a state-owned legal entities, which were subsequently incorporated to the next stage privatization.

However, over time, the problem of growing repression of small shareholders in the ownership structure of companies emerged in the process of transformation, as "new managers" came from the ranks of former directors of these same companies from the time of socialism, who, with the help of political and long-established economic the connection slowly took over the ownership of the companies, which will become fully apparent in the second stage of privatization.

The conversion started without careful preparation, which was to include a market assessment of the value of sociallyowned enterprises that entered the conversion process. Considering that Croatia was a war zone at the time, it was necessary to assess whether any investment in the aggression-affected country was worth the foreign capital.

Also, the conversion itself could not be regulated solely by a single legal act without having prepared and adopted other legal frameworks that would normalize other segments of society inherited from socialism (banking system, land ownership, social housing problem). ownership, etc.).

Another problem related to the fact that natural persons (employees) as owners of shares / stocks did not have ownership rights over the company, but only management rights in proportion to the paid-up amount of the purchased shares / stocks. Also, if it is taken into account that the employees and former employees of the conversion company received favorable loans for the purchase of shares / stocks, which they had to repay within 5 years, then they could not fully own the shares / stocks because, In the event that the loan could not be repaid within the given time, the outstanding shares were transferred to the state fund.

Upon completion of the conversion process, it became clear that the process itself did not bring any improvement to the Croatian economy, but it created conditions for the stratification of society into those who, through their many years of work, created capital in the companies, and then, in the privatization process, they were tricked and pushed to the margin, and to that small group of individuals who used their political and economic ties, upgraded them with new ones and paved the way for the "tycoonization" of the Croatian economy.

\subsection{Privatization}

The second phase of privatization, with the aim of transferring state-owned to private ownership, was carried out through two models: by selling and transferring, without compensation, shares, stocks, rights and things to natural and legal persons, through so-called coupon privatization or "voucher privatization" [37].

The second model - coupon privatization, which carried out free distribution of shares to a certain category of natural persons through privatization investment funds established for this purpose, was a key moment in this segment of the overall transformation of the economic system.

The course of privatization will show that these funds, as intermediaries in the sale of shares through the securities market, were not needed, because after the stage of collecting coupons and exchanging them for privatization shares, which were placed on the market, the true owners no longer had information about the fate of their shares. Which deprived them of the ability to control and supervise until the share repayment.

Also, it was legally possible that the accumulated funds were managed by the owners of several funds, which practically came to the newly acquired capital with no invested own funds, except for the initial, legally prescribed capital in the form of a guarantee deposit, and they realized many times more benefits through coupon privatization.

\subsection{The Results of the Audit and the Consequences of Transformation and Privatization}

In the period from 2001 to 2004, the audit of the transformation and privatization was carried out, which included 1,556 socially-owned enterprises. According to data from the 2004 Transformation and Privatization Audit Work Report, devastating data were identified - only 75 companies were properly converted and privatized [38].

The key irregularities were related to

1. the initial failures (intentional and unintentional) related to the evaluation of the assets of socially-owned enterprises before entering the conversion and privatization process;

2. the negative business policies of these companies after conversion in the sense of failure to cope with market conditions and the unlawful withdrawal of capital from them, which resulted in the dismissal of employees and the initiation of bankruptcy;

3. reduction of the rights and influence of "small shareholders" in the decision-making process, as a consequence of the fact that employees and former employees, for certain reasons - ignorance, disinformation, inability to settle credit obligations, sold or transferred shares to other acquirers;

4. certain omissions in the legislation, which lacked the protection of the rights of "small shareholders" and employees from abuses in changing ownership structure and dismissals, as well as the absence of provisions on criminal and misdemeanor sanctions for violations of 
legal regulations governing the transformation and privatization process, in particular in cases of breach of contractual obligations of large shareholders (e.g. failure to comply with recapitalization obligations, repayment deadlines, misjudgment of company value, etc.);

5. the absence of an independent institution that would oversee the transformation and privatization process instead of the Croatian Privatization Fund, established with the task of implementing and controlling the said procedures. The Fund itself, as the main supervisory body, was subject to political influence by the very fact that the President of the Fund, deputies, vice-presidents were appointed and dismissed by the Government, and appointed by the members of the Supervisory and Management Board of the Fund.

The audit of the identified omissions revealed that Croatia entered the process of conversion and privatization unprepared, since this process should be followed only after the basic legislative and political framework for introducing a market economy has been established.

"Five key aspects of the institutional environment are vital for the implementation of a privatization program: property rights, contract law, entry and exit laws, securities laws, and political stability" [39].

The lack of constructing such an institutional environment opened the door for criminalization of conversion and privatization. In the absence of independent control mechanisms and the impossibility of sanctioning criminal activists, whose privileged position is reflected in their firm connection with political centers of power, a message was sent to the whole society "that political connections and loyalty, and sometimes ignoring and sometimes overtly, bring about the fastest entrepreneurial effect. disregard for the market rules of the game" [40]. In these processes, the public recognized the opportunity for a rapid enrichment of certain interest groups, while the majority of participants remained playful, thus creating "a unique type of system, capitalism with a Croatian face. This system was supposed to rely on 200 Croatian families, that would take over the economoy and begin the initial accumulation of capital, thus creating a new entrepreneurial class that would lead the country towards a profound transformation. This transformation could occur only by using political power an by eliminating all competitors... and by discouraging foreign investors that could appear and pretend to buy already well established economic ventures" [41].

The trend of making of certain groups rich has continued, which is evident from the data of Knight Frank, published in The Wealth Report in 2017, which show that in 2006, 90 citizens with assets in excess of $\$ 30$ million were registered in Croatia only to increase to 120 persons in 2015 and 2016, compared to the total population in Croatia - 4,130,304. Thus, in the period from 2006 to 2016 , the number of richest citizens increased by $25 \%$, while projections show that in 2026, their number will increase to 130 persons with assets exceeding $\$ 30 \mathrm{~m}$.

A comparison with other Central and South Eastern European transition countries is shown in Table 1.

Table 1. Country-level wealth distribution $-\$ 30 m+$.

\begin{tabular}{llllll}
\hline Countries & Population & $\mathbf{2 0 0 6}$ & $\mathbf{2 0 1 5}$ & $\mathbf{2 0 1 6}$ & \\
\hline Bulgaria & $7,000,119$ & 50 & 70 & $\mathbf{2 0 2 6}$ & 80 \\
Croatia & $4,130,304$ & 90 & 120 & 120 & 130 \\
Czech Republic & $10,689,209$ & 210 & 270 & 280 & 210 \\
Hungary & $9,684,679$ & 150 & 190 & 10 & 250 \\
Romania & $19,364,557$ & 120 & 170 & 200 \\
\hline
\end{tabular}

Source: https://content.knightfrank.com/research/83/documents/en/the-wealth-report- 2017-4482.pdf. [42]

https://www.worldometers.info/world-population/population-by-country. [43].

Consequences of conversion and privatization have had a negative impact on the economy, but also on society as a whole, undermining the legitimacy and credibility of these processes, especially in light of the fact that the privatization process is not yet complete and public resistance to further privatization is increasing.

\section{Conclusion}

The prerequisite for the implementation of structural reforms in the system of public administration, justice, health, education is the reform of the political system.

The course of transformation of the political system, which has existed in Croatia for the past 29 years, has shown that democratization of the party system (through the reform of political parties) is a precondition for the democratization of society.
The undemocratic organizational structure and current way of functioning of political parties are generators of social and economic crises in Croatia. The prevalence of corruption, which today represents a systemic phenomenon, a constant conflict of interest, and political clientelism as a pattern of action of the political elite, finds its drawing on the existing party system.

During the transformation of the political system, Croatia has built a legislative and institutional framework that provides a democratic way of electing power, but, in its totality, the political system itself is not fully democratized, in a way specific to Western countries with a long democratic tradition.

As a rule, the two strongest political parties, which change in power during the election cycle, are burdened with an oligarchic way of functioning within their parties, and map the same mode of governance to society itself, ruling in the 
interests of individuals and groups, not the welfare of all citizens.

It is this ability to govern in the interests and for the benefit of the entire community that makes the political system democratic, providing the conditions for building a society, with a new value system, based on the principles of justice and fairness.

Transformation of political parties into democratic organizations requires the political will of their leaders and officials, as well as gaining awareness of the need to change the existing political culture.

Croatia made the biggest progress in the democratization of the political system during the EU membership negotiation process, when it was forced to implement the acquis in national law, however, practice has shown that, after joining the EU, Croatia has stopped further democratization.

This fact points to the conclusion that the imposition of "rules of the game" from the outside, without the political will of the domestic power-holders to implement structural reforms, and their awareness of accountability to their own electorate does not produce the expected results.

\section{References} [1] Ivo $\quad$ Josipović
https://officialsite.pp.ua/?p=327624.

[2] Horowitz, S. (2003). War After Communism: Effects on Political and Economic Reform in the Former Soviet Union and Yugoslavia, Journal of Peace Research, Vol. 40, No. 1, Jan., pp. 25-48.

[3] World Bank (2000). Anticorruption in transition: A Contributrion to the Policy Debate, Washington DC: World Bank.

http://siteresources.worldbank.org/INTWBIGOVANTCOR/Re sources/contribution.pdf.

[4] McFaul, M. (2002). The Fourth Wave of Democracy and Dictatorship-Noncooperative Transitions in the Postcommunist World, World Politics 54 (January), pp 21244.

[5] Stefes, C. H. (2008), Governance, the state and systematic corruption: Armenia and Georga in comparation, Caucasian Review of International Affairs, Vol. 2 (2), Spring 2008.

[6] Kuzio, T. (2001). Transition in Post-Communist States: Triple or Quadruple?, Politics, Vol. 21 (3), pp. 168-177.

[7] Bandelj, N. \& Radu, B. (2006)., Consolidation od Democracy in Postcommunist Europe, Center for the Study od Democracy, University of California, Irvine, Paper 06-04.

[8] Vojnović, D. (2013). Ekonomija i politika tranzicije. Polja stoljeća povijesti reforme socijalizma i tranzicije 1962.-2012., Rad Hrvatske akademije znanosti i umjetnosti, Razred za društvene znanosti, 50=516 (2013): pp. 153-186.

[9] Welsh, H. A. (1994). Political Transition Processes in Central and Eastern Europe, Comparative Politics, Vol. 26, No. 4 (Jul., 1994), pp. 379-394.

[10] Braji, I., Nigeria: From Democracy To Kakistocracy.
http://www.gamji.com/article6000/NEWS7592.

[11] Dahl, R. A. (1973). Polyarchy: Participation and Opposition, New Haven and London, Yale University Press.

[12] United Kingdom Department for International Development (2006), Eliminating World Poverty: Making Governance Work for the Poor, Norwich, U.K.: Stationery Office. http://www.gov.uk/government/uploads/system/uploads/attach ment_data/file/272330/6876.pdf.

[13] Ekiert, G., Kubik, J. and Vachudova, M. A. (2007). Democracy in th Post-Communist World: An Unending Quest?, East European Politics and Societies, 21, 7.

[14] Gebethner, S. (1997). Free Elections and Political Parties in Transition to Democracy in Central and Southeastern Europe, International Political Science Review, Vol. 18, No. 4, pp. 381-399.

[15] Mašić, B. (2010). Stranačka stuktura Hrvatskog sabora 1990.2000., Pravnik, Vol. 44, No. 89, Udruga Pravnik, Zagreb, pp. $67-82$.

[16] Pickering, P. M \& Baskin, M. (2008). What is to be done? Succession from the League of Communists of Croatia, Communist and Post-Communist Studies 41, pp. 521-540.

[17] Stoica, C. A. (2012.). "Our Martyrs of 1989 Did Not Die for This!": Political Capitalism in Post-Communist Romania, Historical Social Research, Vol. 37 - 2012 - No. 2 2012: 2652.

[18] Ragazzi, F. (2009). The Invention of the Croatian Diaspora: Unpacking the Politics of "Diaspora" During the War in Yugoslavia, Center for Global Studies, Project on Global Migration and Transnational Politics, Working Paper no. 10, November.

http://www.gmu.edu/centers/globalstudies/publications/gmtpw p/gmtp_wp-10.pdf.

[19] Jandrić, B. (2003). Stajališta Hrvatske političke emigracije o hrvatskom proljeću, Časopis za suvremenu povijest, God. 35 , br. 2, pp. 431-461.

[20] Kolstø, P. (2010). Bleiburg: The Creation of a National Martyrology, Europe-Asia Studies, Vol. 62, No. 7, September, pp. 1153-1174.

[21] Burg, S. L. (1977). Ethnic Conflict and the Federalization of Socialist Yugoslavia: The Serbo-Croat Conflict, Publius, Vol. 7, No. 4, Federalism and Etnicity, Autumn, pp. 119143 .

[22] Dolenec, D. (2008), Europeanization as a Democratising Force in Post-communist Europe: Croatia in Comparative Perspective, Politička misao, Vol. XLV., No. 5, pp. 23-46.

[23] Gunther, R. (2005), Parties and Electoral Behavior in Southern Europe, Comparative Politicis, Vol. 37, No. 3 (Apr.), pp. 253-275.

[24] Merriam-Webster Dictionary.http://www.merriamwebster.com/dictionary/dirigiste.

[25] Keppel, F. P. (1916). Reviewed Work: Stakes of Diplomacy. by Walter Lippmann, Political Science Quarterly, Vol. 31, No. 2, (Jun.), pp. 318-321.

[26] Sajó, A. (2007). Understanding Post-Communist Corruption, An Conference on Public Integrity and Anticorruption in the Public Service, Bucharest, 29-30 May 2007. 
[27] Issacharoff, S. (2010). On Political Corruption, Harvard Law Review, Vol. 124, No. 1, November, pp. 118-142.

[28] Robinson, A. James \& Verdier, T. (2013). The Political Economy of Clientelism, The Scandinavian Journal of Economics, 115 (2), 260-291.

[29] Frier, D. A. (1969). Conflict of interest in the Eisenhower administration. USA: Iowa State University.

[30] Cathcick, P. (2014). Conflict of interest: Gateway to Corruption, Association of Certified Fraud Examiners (ACFE) European Fraud Conference.

[31] Robles-Egea, A. \& Aceituno-Montes, J. M (2012). Clientelistic Relationships and Political Corruption: The Shortcoming of Democracy (Andalusia, a study case), Paper presented to Panel "Cooperation boundaries, shifting power", Session RC37 "Rethinking Political Development", IPSA XXII World Congress of Political Science, Madrid, July 8 to $12,2012$.

[32] Savas, E. S. (1992). Privatization in Post-Socialist Countries, Public Administration Review, Vol. 52, No. 6 (Nov. - Dec.,), pp. 573-581.

[33] Izyumov, A. \& Claxon, T. (2009). Models of Capitalism and Income Distribution in Transition Economies: A Comparative Perspective, Journal of Economic Issues, Vol. XLIII, No. 3, September.

[34] Kosals, L. (2007). Essay on Clan Capitalism in Russia, Acta Oeconomica, Vol. 57, No. 1 (March), pp. 67-85.

[35] Peev, E. (2002). Ownership and Control Structures in
Transition to "Crony" Capitalism, Eastern European Economics, vol. 40, no. 5, September-October, pp. 73-91.

[36] Gregurek, M. (2001)., Stupanj i učinci privatizacije u Hrvatskoj, Ekonomski pregled, 52 (1-2), st. 155-188.

[37] Török, L. (2011)., A Case Study of Privatization without Consideration: The Failure of Voucher Privatization in the Czech Republic, Club of Economics in Miskolc, TMP Vol. 7, Nr. 2, pp. 79-86.

[38] Izvješće o radu na provedbi revizije pretvorbe i privatizacije (2004) - www.revizija.hr/hr/articles/view/55/revizijepretvorbe-i-privatizacije.

[39] Balfour, M. \& Crise, C. (1993)., A Privatization Test: The Czech Republic, Slovakia and Poland, Fordham International Law Journal, Volume 17, Issue 1, Article 3, (84-125).

[40] Čučković, N., (2002), Siva ekonomija i proces privatizacije u Hrvatskoj, 1997. 2001., Financijska teorija i praksa, 26 (1), str. 245-271.

[41] Grubiša, D. (2005)., Political Corruption in Transitional Croatia: The Pecularities of a Model, Politička misao, Vol. XLII, No. 5, pp. 55-74.

[42] Knight Frank (2017), The Wealth Report https://content.knightfrank.com/research/83/documents/en/the -wealth-report-2017-4482.pdf.

[43] https://www.worldometers.info/world-population/populationby-country/. 